\title{
Articles
}

\section{Gender Role Conflict Model of Pastors' Husbands at Batak Karo Protestant Church}

\author{
Karina Meriem Beru Brahmana*ab, Suryanto Suryanto ${ }^{b}$, Bagong Suyanto ${ }^{c}$
}

[a] Faculty of Psychology, Nommensen HKBP University, Medan, Indonesia. [b] Faculty of Psychology, University of Airlangga, Surabaya, Indonesia. [c] Faculty of Social Sciences and Political Sciences, University of Airlangga, Surabaya, Indonesia.

\begin{abstract}
This research aims to propose a gender role conflict model of GBKP (Protestant Batak Karo Church, Indonesia) pastors' husbands with masculine ideology, marital adjustment, and self-esteem as mediators, using SEM-PLS (Structural Equation Model-Partial Least Squares). In order to measure gender-role conflict, the four-point gender-role conflict scale developed was used. The Male Role Norms Scale (MRNS) was used to measure masculine ideology, the Dyadic Adjustment Scale (DAS) was used to measure marital adjustment and The Rosenberg Self-Esteem Scale (RSE) was used to measure self-esteem. The subjects of this research were 79 pastors' husbands at Batak Karo Protestant Church. From the five proposed hypotheses, two were accepted and three were rejected. The two accepted hypotheses were the effect of masculine ideology towards gender-role conflict and the effect of marital adjustment towards gender-role conflict. Meanwhile, the hypotheses of the effects of both masculine ideology and marital adjustment towards self-esteem, as well as the effect of self-esteem towards gender-role conflict were rejected.
\end{abstract}

Keywords: gender role conflict model, masculine ideology, marital adjustment, self esteem

Interpersona, 2019, Vol. 13(2), 127-143, https://doi.org/10.5964/ijpr.v13i2.360

Received: 2019-04-09. Accepted: 2019-10-30. Published (VoR): 2019-12-20.

*Corresponding author at: Faculty of Psychology, Nommensen HKBP University, Jl. Sutomo No. 4A, Medan, North Sumatera, Indonesia. E-mail: ina_brahmana@yahoo.com

This is an open access article distributed under the terms of the Creative Commons Attribution 4.0 International License, CC BY 4.0 (https://creativecommons.org/licenses/by/4.0/), which permits unrestricted use, distribution, and reproduction in any medium, provided the original work is properly cited.

Karo is one of the Batak tribes from North Sumatra, Indonesia. It is a tribe that strongly holds patriarchal values, where males hold the highest authority. Being patriarchal, this tribe also generally differentiates people based on gender, not only from physical differences but also from how men and women should live in society (Bangun, 1981). These differences can be seen in the rights and obligations of each gender. For instance, manual labor is a job exclusive for men, while cooking is a women-only task.

In Karo culture, men taking on tasks that do not fit their gender roles can reduce and lower their dignity. A man who often does female tasks is usually called pa diberu, which means a man who is commanded by his woman or "lady-like" (Bangun, 1981). In this culture, a household (also called jabu) always uses the man's family name and never the woman's family name. This culture places males or husbands as the only ones who can make decisions (Bangun, 1981). Furthermore, the higher a male position versus their women, the greater shall be his social respect. For example, in a traditional ceremony or family gathering, men sit in higher and more honorable places than women (Bangun, 1981). 
Social demands for the male position apply to all Karo men, without exception, even to the GBKP (Gereja Batak Karo Protestan, or Protestant Batak Karo Church) pastor's husbands. As a male from the Karo tribe, a husband is generally expected to become the family leader and influencer. Moreover, the patrilineal cultural system claims that male is the best gender in many fields. However, the case is usually different if a man marries a female pastor in GBKP. As a pastor's husband, he is expected to be able to support her, to complement her spiritual and daily life, to remind her to give a good service to the congregation, neither interfere, nor to control her work, as well as not to become an obstacle in his wife's service (PPWG GBKP, 2014). By those demands, it can be seen that being a GBKP pastor's husband is culturally not easy.

The moral responsibility for a pastor's husband is based on the extensive scope of a pastor's services (as a shepherd, teacher and leader) in different places. Due to their high demands, pastors hardly take on active roles in the household. For that reason, their husbands do the housework, voluntarily or forced, as the only way these roles can be fulfilled.

Besides doing tasks that are opposite to their gender roles, these husbands are also faced by situations in which they must resign from their jobs to join their wives in service. This is because a pastor's job often demands readiness to be relocated at any time, which tend to cause difficulties in a partner's full-time job. Therefore, most husbands would decide to resign and follow their wives in service, or to start a business. The conditions in which husbands cannot optimize and develop themselves in jobs that they desire, puts them into unpleasant or rather dilemmatic situations. These generally imbalanced conditions often bring the husband problems. In this case, he is compelled to abandon his ego as a man and support his wife by looking after the children, doing the household, as well as picking her up and dropping her off to the church.

The gap between the expected gender role and reality tends to make the husband feel powerless, passive, inferior, lacking confidence, unable to thrive and even pressured by having no passion or job. This can cause him an inner conflict which is called a gender-role conflict. According to O'Neil (2008), this conflict in men is the psychological condition resulting from the male gender role socialization in ways that bring negative consequences for himself and others. Generally, such a conflict occurs when gender roles are seen as strict, confined, or even limited to self or others (O'Neil, 1981). Its final result is a limitation to a person's or others' potential.

A preliminary interview suggests that the cause of gender role conflict in pastors' husbands is the existence of a gap or conflict between their current role and the one that has been cultivated since they were children. Masculine ideology, according to Pleck (1995), is the belief in the importance of a person to follow cultural standards of male behaviors that have been set and involved in supporting cultural belief system about masculinity and the male gender role. Relationship with others can be interfered if a man finds that his ideology does not match reality. This can be experienced by the pastors' husbands once the masculinity principle that has been internalized since their early age differs from their reality.

Other than the effect of masculine ideology, gender role conflict experienced by males can generally appear in contexts such as gender role transition (O’Neil \& Egan, 1992). Transition period after marriage and having children also occurs to pastors' husbands. Entering such a period for males, according to O'Neil (2008), is not easy because of the multitude of differences they must face, mainly in their gender roles as a husband or a father. Then, along with the demands that must be fulfilled, men must be able to adapt in domestic life and try to adjust in marriage life. 
According to Hurlock (1991), marital adjustment is a process of adaptation between husband and wife in order to prevent and solve conflicts through their adjustment process. Marital adjustment is also a continuous process by which two individuals learn to accommodate to each other's needs, desires, and hopes in order to achieve happiness in a relationship (Laswell \& Laswell, 1987). But marriage life does not always run smoothly and broken expectations often lead to conflict.

According to Arond and Pauker (as cited in Olson \& DeFrain, 2003), the main conflict causes among newlywed couples relate to domestic tasks. Research conducted by Edward Bader and partners (as cited in Olson \& DeFrain, 2003) also found that from the first six months to the first five years of marriage, housework issues still give rise to the main conflicts in a household. The domestic tasks distribution cannot be taken as trivial, especially for males (Mintz \& Mahalik, 1996). Men who come from families that hold values of masculinity tend to find it difficult to face such tasks.

Generally, men hide their feelings related to gender role demands that they must fulfill. According to Wood and Eagly (2002), they are expected to show agentic traits or masculinity, such as confidence, superiority, ability to make decisions, activeness, independence, ability to face pressures and tenacity. Despite that fact, gender roles that are not in line with these expectations can reduce male self-esteem. Self-esteem is a positive selfimage which includes positive self-confidence (O'Neil, 2008). Men tend to carefully hide their uncomfortable feelings from threatening their strength (ego) in relationships and at work. Gender roles which are not in line with the expected demands can lower male self-esteem, causing an inner conflict. This is called a gender role conflict.

This research on gender-role conflict in husbands of GBKP pastors considers several inputs and critics provided by previous studies. James O'Neil (2008), as the founder of gender-role conflict, believed that gender role conflict still needs to be conceptually and empirically renewed since, from the start, its model had not been directly aimed to multicultural and diversity issues related to gender role socialization (O'Neil, 2008). Criticisms by several other researchers state that a more complex model is required in order to explain the factors behind gender-role conflict (O'Neil 2008). Moderating variables and moderators were also suggested to be included in order to correctly determine how this conflict impacts psychological inability (Good, Walther, \& Heppner, 1995). All of these criticisms benefit and support the development of a gender role conflict research model that is more contextually complex.

The aims of this study were to examine the following hypotheses (Hs):

H1: Masculine ideology influences the gender role conflict of GBKP pastors' husbands, whose high masculine ideology generally experience high gender role conflicts and vice versa.

H2: Masculine ideology influences the dignity of GBKP pastors' husbands, whose high masculine ideology generally show low self-esteem and vice versa.

H3: Marital adjustment affects the gender role conflict of GBKP pastors' husbands, whose high marital adjustments generally show low gender role conflicts and vice versa.

H4: Marital adjustments affects the self-esteem of GBKP pastors' husbands, whose high marital adjustments generally show high self-esteem. 
H5: Self-esteem affects the gender role conflict of GBKP pastor's husbands, whose high self-esteem generally show low gender role conflicts and vice versa.

\section{Method}

\section{Procedure and Participants}

Participants were 79 husbands of GBKP pastors that met the criteria of having been married for 1 year, having at least 1 child, coming from the Karo tribe, being members of the GBKP since before marriage and not working as an active pastor. This research was conducted by distributing the several measuring instruments to the participants, such as an online questionnaire (Google Form), e-mail and paper based questionnaire distributed throughout the Protestant Karo Batak Churches (GBKP), in Indonesia.

\section{Instruments}

This research consists of four variables: masculine ideology, marital adjustment, self-esteem, and gender-role conflict. Masculine ideology is measured by using The Male Role Norms Scale (MRNS), by Thompson and Pleck (1986). Marital adjustment is measured using The Dyadic Adjustment Scale (DAS) from Spanier (1976). Self-esteem is measured using The Rosenberg Self-Esteem Scale (RSE), developed by Rosenberg (1979). Gender-role conflict is measured using The Gender Role Conflict Scale by O'Neil et al. (1986).

Based on pilot trial of masculine ideology items using Lisrel 8.50, it is found that out of 26 items on masculine ideology, 17 were valid, while the other 9 were not. From the item trial on marital adjustment, out of 32 items, 21 items were valid and 11 were not. Meanwhile, item trial on self-esteem using Lisrel 8.50 indicated that from 10 items, 4 items were valid and 6 were not. Finally, for gender-role conflict 37 items, 23 items were valid and 14 were not.

\section{Data Analyses}

This study was analyzed using Smart PLS (Partial Least Squares) V. 3 Professional. PLS is a variance-based structural equation analysis (SEM) which can simultaneously conduct measurement as well as structural model testing. Data processing with PLS is done in two stages (testing the outer and the inner model). The outer model aims at testing the validity and reliability, while the inner one is used to test the model and the research hypotheses (Abdillah \& Hartono, 2015).

\section{Results}

\section{Stages of Outer Model Testing}

Outer model testing is conducted on the whole variables. The indicator criteria of variables is said to be construct valid and reliable if it has a factor loading score of $\leq 0.5$ and the t-test score is $>1.96$. Figure 1 shows the outer model testing on each variable. 


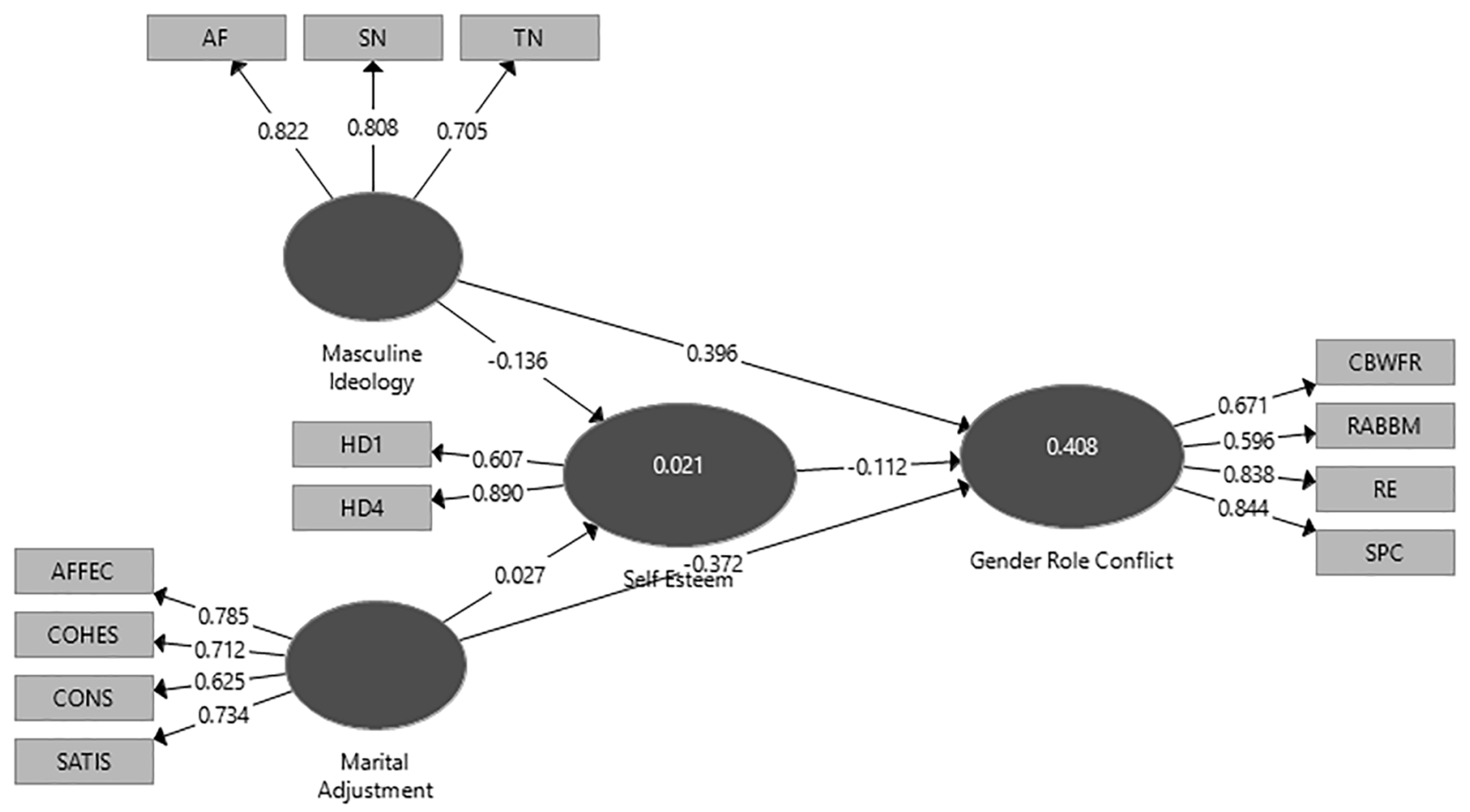

Figure 1. Outer Model of gender role conflict of GBKP pastor's husbands.

Note. AF = Anti Femininity; SN = Status Norm; TN = Toughness; HD1 = Self Esteem 1th indicator; HD4 = Self Esteem 4th indicator; AFFEC = Affectional Expression; COHES $=$ Dyadic Cohesion; CONS $=$ Dyadic Consensus; SATIS $=$ Dyadic Satisfaction; CBWFR = Conflict Between Work and Family Relations; RABBM = Restrictive Affectionate Behavior Between Men; RE = Restricted Emotionality; SPC = Success/Power/Competition .

\section{Convergent Validity}

The convergent validity can be seen from the factor loading score and the calculated t-value. The loading factor is considered valid if the score is above (>) 0.5 (Chin cited in Ghozali, 2014). However, according to Hair et al. (1998), a factor loading score $>0.3$ can still be accepted, although a score $>0.4$ is preferable. Based on statistics, the factor loading from all indicators/items in these variables were $>0.5$.

\section{Construct Validity}

The next measurement model was the Average Variance Extracted (AVE), which is the score for the indicator variance contained within the latent variable. This construct is considered with a good validity if AVE is $>0.5$ (Ghozali, 2008). From statistical calculation, AVE for all variables was $>0.5$.

\section{Discriminant Validity}

Discriminant validity was measured using a cross loading value. A high cross loading value $(>0.5)$ of certain variable indicators when compared to another suggests that the construct validity in latent variables is good. Table 1 describes this value for each variable. 
Table 1

Discriminant Validity With Cross Loading of Variables

\begin{tabular}{|c|c|c|c|c|}
\hline Indicator & Self Esteem & Gender Role Conflict & Masculine Ideology & Marital Adjustment \\
\hline \multicolumn{5}{|c|}{ Masculine Ideology } \\
\hline Anti-Femininity & -0.619 & 0.494 & 0.822 & -0.246 \\
\hline Status Norm & 0.013 & 0.382 & 0.808 & -0.207 \\
\hline Toughness & -0.166 & 0.288 & 0.705 & -0.186 \\
\hline \multicolumn{5}{|c|}{ Self Esteem } \\
\hline HD1 & 0.607 & -0.123 & -0.021 & 0.177 \\
\hline HD4 & 0.890 & -0.168 & -0.166 & -0.022 \\
\hline \multicolumn{5}{|c|}{ Marital Adjustment } \\
\hline Affectional Expression & 0.067 & -0.342 & -0.154 & 0.785 \\
\hline Cohesion & 0.026 & -0.436 & -0.148 & 0.712 \\
\hline Consensus & -0.072 & -0.212 & -0.158 & 0.625 \\
\hline Satisfaction & 0.119 & -0.345 & -0.335 & 0.734 \\
\hline \multicolumn{5}{|c|}{ Gender Role Conflict } \\
\hline SPC & -0.081 & 0.844 & 0.589 & -0.338 \\
\hline $\mathrm{RE}$ & -0.181 & 0.838 & 0.319 & -0.400 \\
\hline RABBM & -0.243 & 0.596 & 0.313 & -0.167 \\
\hline CBWFR & -0.121 & 0.671 & 0.266 & -0.513 \\
\hline
\end{tabular}

Note. Numbers in bold means that the indicators in each variable have a greater correlation than the other variables, so it can be concluded that the variable passed the discriminant validity test. AF = Anti Femininity; SN = Status Norm; TN = Toughness; HD1 = Self Esteem 1th indicator; HD4 = Self Esteem 4th indicator; AFFEC = Affectional Expression; COHES = Dyadic Cohesion; CONS = Dyadic Consensus; SATIS = Dyadic Satisfaction; CBWFR = Conflict Between Work and Family Relations; RABBM = Restrictive Affectionate Behavior Between Men; RE = Restricted Emotionality; SPC = Success/Power/Competition.

\section{Reliability (Goodness of Fit)}

A construct is considered reliable if the composite reliability is high compared to the alpha coefficient (Raykov, 2001). In this case, composite reliability must be $>0.7$, although $>0.6$ is still acceptable (Hair et al., 2006; Hartono \& Abdillah, 2014), or a score larger than its Cronbach's alpha. Table 2 shows the results of Cronbach's alpha $(\alpha)$ and Composite reliability $(C R)$.

Table 2

Reliability

\begin{tabular}{lcc}
\hline Variable & $\boldsymbol{\alpha}$ & $\mathbf{C R}$ \\
\hline Gender Role Conflict & 0.73 & 0.83 \\
Marital Adjustment & 0.70 & 0.81 \\
Masculine Ideology & 0.69 & 0.82 \\
Self Esteem & 0.30 & 0.73 \\
\hline
\end{tabular}

\section{Inner Model Testing Stage}

The inner model testing is conducted in two stages, which is through goodness of fit and research hypothesis. Calculation results can be seen in the figure 2 . 


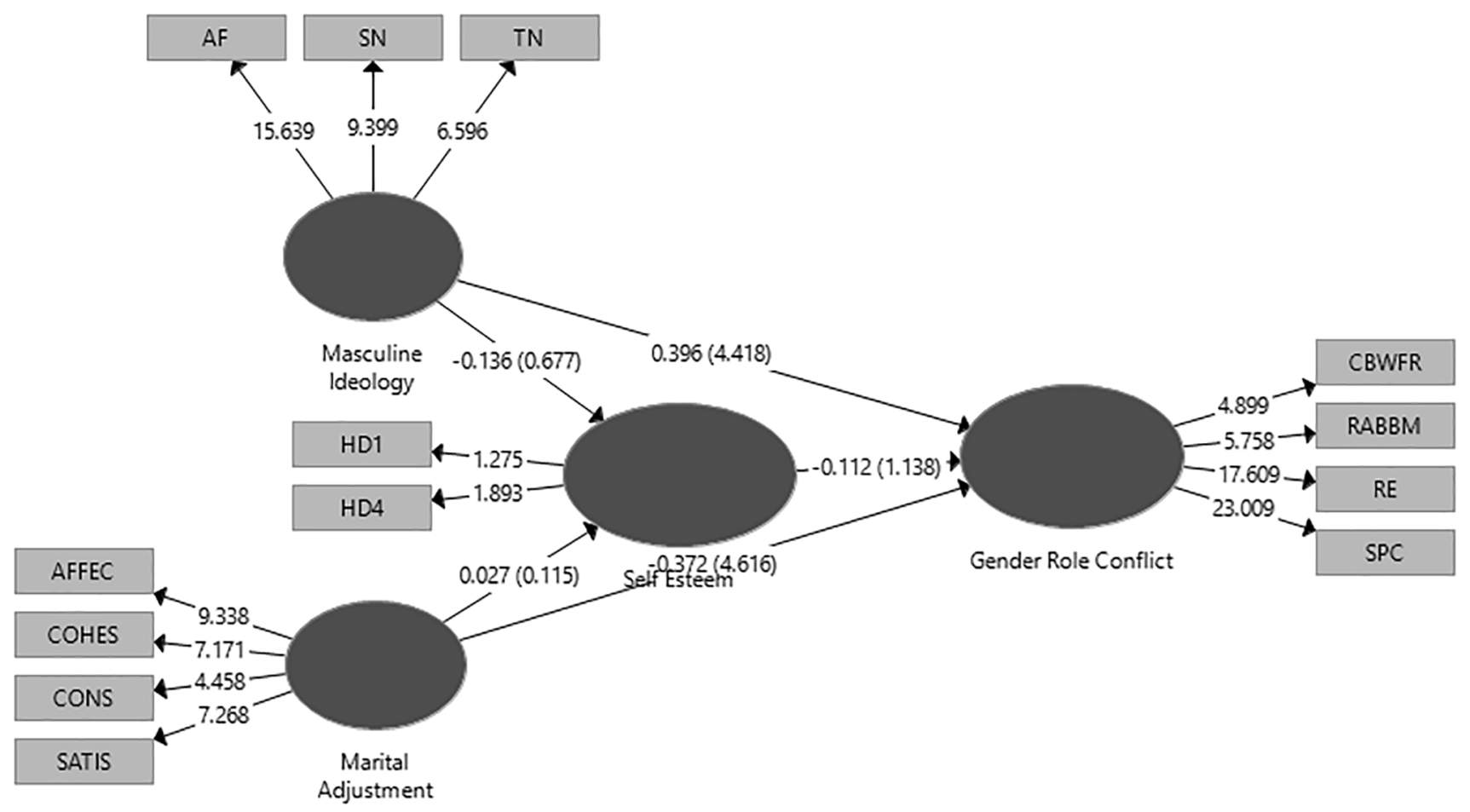

Figure 2. Inner model of gender role conflict of GBKP pastor's husbands.

Analysis on the inner model is conducted to determine whether the structural model has been accurately built. To evaluate the inner model, several indicators can be evaluated:

\section{Determinant Coefficient $\left(\mathbf{R}^{2}\right)$}

Testing on the inner model using R-square is part of the goodness of fit model. Chin (cited in Abdillah \& Hartono, 2015) explains that the criteria for $R^{2}$ are three categories, which are good (0.67), medium (0.33) and low (0.19). $R^{2}$ of gender-role conflict was 0.41 (medium) and $R^{2}$ of self-esteem was 0.02 (low).

\section{Predictive Prevalence $\left(\mathbf{Q}^{2}\right)$}

A $Q^{2}$ value in this research was .42 . It can be concluded that masculine ideology, marital adjustment, and selfesteem have a good prediction of gender-role conflict.

\section{Goodness of Fit Index (GoF)}

The final step is to determine the Goodness of Fit Index (GoF). According to Tenenhaus (in Abdillah \& Hartono, 2015), GoF value is divided into 3 categories: low (0.1), medium (0.25) and high (0.38). The average AVE was 0.56 , while the $R^{2}$ average was 0.215 . By the above formula, the GoF in this research was 0.348 (medium).

\section{Hypothesis Testing}

Hypotheses were tested by comparing the t-value from PLS with t-table. Table 3 presents the estimate values of each relationship among variables. 
Table 3

Testing of Direct Influence Between Variables

\begin{tabular}{lccc}
\hline Inter-Variable Relation & Original Sample (O) & t Statistics & Conclusion \\
\hline Masculine Ideology $\rightarrow$ Gender Role Conflict & 0.396 & 4.418 & Approve \\
Masculine Ideology $\rightarrow$ Self Esteem & -0.136 & 0.677 & Reject \\
Marital Adjustment $\rightarrow$ Gender Role Conflict & -0.372 & 4.616 & Approve \\
Marital Adjustment $\rightarrow$ Self Esteem & 0.027 & 0.115 & Reject \\
Self Esteem $\rightarrow$ Gender Role Conflict & -0.112 & 1.138 & Reject \\
\hline
\end{tabular}

Based on such hypothesis testing, Figure 3 presents this study's newest model.

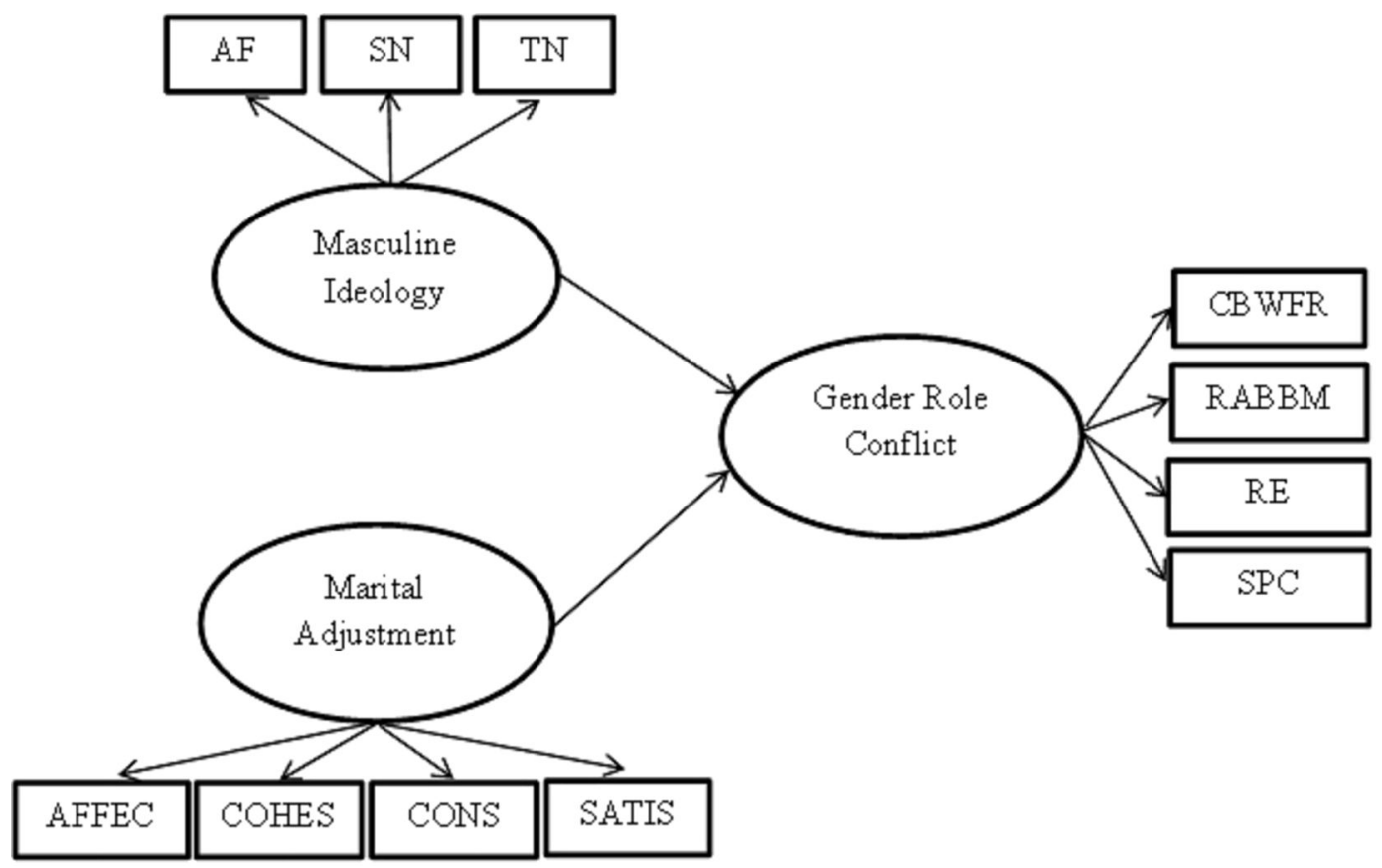

Figure 3. The Gender-Role Conflict Model of GBKP pastor's husbands based on hypothesis testing.

Note. $\mathrm{AF}=$ Anti Femininity; $\mathrm{SN}=$ Status Norm; $\mathrm{TN}=$ Toughness; $\mathrm{AFFEC}=$ Affectional Expression; $\mathrm{COHES}=$ Dyadic Cohesion; CONS = Dyadic Consensus; SATIS = Dyadic Satisfaction $;$ CBWFR = Conflict Between Work and Family Relations; RABBM = Restrictive Affectionate Behavior Between Men; RE = Restricted Emotionality, SPC = Success/Power/ Competition.

\section{Discussion}

\section{Masculine Ideology Affects Gender Role Conflict}

According to Pleck (1995), masculine ideology is one's belief in the importance of following cultural standards for men, as well as their involvement in supporting the internalization of the masculinity belief system. By a strong masculine ideology, men are expected to achieve the standard behaviors that are appropriate to the demands in their culture or environment. 
Pleck (1995) stated that one scenario where men cannot achieve the masculine ideology standards is at a transition period in their gender roles, e.g., adolescence, becoming a father or losing loved ones. Gender role transition is an event in the developmental stage of gender role where men are forced to change their roles or oppose the assumptions related to their gender roles. Generally, this will result in the emergence of gender role conflict (O’Neil \& Egan, 1992; O’Neil et al., 1987; O’Neil \& Fishman, 1992).

According to O'Neil (2008), gender role conflict is usually closely related to the socialization of gender roles and the masculine ideology that it entails since childhood. The negative effects of such a conflict may include stress, depression, drug use, heart attack, alcoholism and suicidal tendencies. Based on the previous results, in this study the masculine ideology significantly affected the emergence of gender role conflict among the pastors' husbands. O'Neil (2008) has indicated similar findings, in which masculine ideology usually causes gender role conflict. According to the interview results, the feelings of inferiority, worthless, lack of confidence and distress usually emerged when the pastors' husbands performed or experienced things contrary to their demands as men.

Their inability to be their families breadwinners or doing house chores (such as children care, dish washing laundry, etc.) are the situations where they cannot fulfill their gender role demands as men of Karo who have higher position than women. As a tribe upholding patrilineal culture, Karo provides special position for men to be leaders and play other important roles, especially in making decision (Tarigan, 2009).

This is in line with Adler's statement (cited in O'Neil, 2015), in which the values of patrilineal culture also contribute significantly to the emergence of such problems. Patrilineal cultural demands men to be resilient in various ways (Williams \& Best, cited in Courtenay, 2000). However, if they cannot properly meet the demands, Liu, Rochlen, \& Mohr (2005) stated that it causes male gender role conflict, particularly within GBKP pastors' husbands.

\section{Masculine Ideology Does Not Affect Self-Esteem}

The second hypothesis was rejected because the masculine ideology did not have significant effect on the husbands' self-esteem. Therefore, factors beyond those investigated were influencing this condition. This finding has contradicted some studies, which stated that masculine ideology highly influences men's low self-esteem (Blazina, 2001; Pleck et al., 1993). According to Pleck, Sonenstein, \& Ku (1993), higher traditional masculine ideology will result in lower self-esteem possessed by a man, if he is confronted or has to perform gender roles that are contradicted with the culture where the masculine ideology is socialized.

According to Levant (cited in Mellinger \& Levant, 2014), masculine ideology has been socialized and instilled by parents, teachers, and peers, especially through social interaction, such as reinforcement, punishment, and observation. Such ideology tells, supports, and limits men to adapt with applied male gender role norms by adopting particular socially approved masculine behaviors and avoiding the forbidden ones (Mellinger \& Levant, 2014).

If men cannot fulfill the expected masculine ideology values in their environment or culture, it can lead to negative consequences, including the emergence of worthlessness and inferiority, because they are not able to negotiate gender roles in different contexts and situations (Blazina, 2001). This result is in line with the interview result conducted by Brahmana and Suyanto (2018) on several GBKP pastors' husbands where they found dif- 
ferences or contradictions between their current roles and the one that has been indoctrinated since they were children. Their inability to be the breadwinner of their families and their duty to help with house chores then contradicted with their ideology as men that had been embraced and socialized by their culture and environment since childhood. Therefore, it caused feelings of worthlessness and inferiority.

However, the result of this research on GBKP pastors' husbands turned out to be quite different and tended to contradict several previous studies. These results found that the masculine ideology owned by GBKP pastors' husband was on an intermediate level, while their high self-esteem was high.

This last finding had similarities with innovative research conducted by Robertson and Verschelden (cited in Good, Borst, \& Wallace, 1994) involving a couple consisting of a stay-at-home dad and a working mom (considered a couple with reverse roles). They've found that the father tended to feel emasculated but was not more feminine than those in general public. In addition, this research subjects did not feel different from other people in terms of self-esteem or psychological well-being. The fathers thought that children could learn from their family structure, so when they get older and form a family, they will freely perform their gender by not being limited to the stereotype (Robertson \& Verschelden cited in Good, Borst, \& Wallace, 1994).

A seminar about cultural customs of Karo in 1977 (in Brahmana, 2003) revealed that the Karo community in general has special traits, such as being honest, brave, tough, well-mannered, tolerant, respecting others, and high self-esteem. The latter is their most common trait. Generally, Karo society maintains high self-esteem. They will do anything and even endure suffering to keep their self-esteem high.

The GBKP pastors' husbands essentially also possess this hereditary life principle and traits. Although many roles contradicted with masculine ideology, they still keep their self-esteem high. Their desire to maintain the family reputation and support their wives - whether it is voluntarily or not - is a proof that the husbands keep their self-esteem high in every situation. In addition, the internalization of cultural values in the Karo tribe becomes one of the supporting factors to keep their self-esteem high. This finding is similar with the statement of Wade and Rochlen (2013), in which the internalization of individual ethnic identity in a particular ethnic group is generally associated with increasing self-esteem.

\section{Marital Adjustment Affects Gender Role Conflict}

The result of statistical analysis in this study showed that the third hypothesis was accepted with a significant result indicating that the marital adjustment significantly affects gender role conflict of GBKP pastors' husbands. As previously mentioned, O'Neil and Egan (1992) argued that male gender role conflict arises due to several factors, including when men enter the transition stage where their internalized masculine roles are challenged.

One example of a transition stage is when men get married which, according to O'Neil (2008), is a challenging stage for them They have to deal with various situations when performing their role as a husband and father. Because of these various gender role demands, they must be able to adjust to their marriage condition.

Disagreement, dispute, or conflict often arise in marriage, including financial problems, children education methods, family relationships, desired activities of the partner, communication and division of household responsibilities (Sadarjoen, 2005). Arond and Pauker (cited in Olson \& DeFrain, 2003) supported these arguments saying that newly married couples commonly face problems about duties or domestic work. 
Division of household responsibilities is not easy, particularly for men (Mintz \& Mahalik, 1996), and the GBKP pastors husbands also face this problem. Basically, they feel objected to do household task since it is contrary to their cultural values. In Karo culture, men are generally raised to become a leader in their tribe and family. The Karo boys have been introduced to their gender roles to become the family leader and main breadwinner since the early age (Bangun, 1981). Thus, if a man's job contradicted with his gender role, it will degrade his dignity and respect towards himself. Bangun (1981) stated that men performing women jobs are called pa diberu or those who are willing to be ordered by their wife. However, as time passes, the pastors' husbands must willingly help their wife doing household chores and nurturing their children.

\section{Marital Adjustment Does Not Affect Self-Esteem}

Adjustment process is the most important stage in marriage, as the individuals come from different cultural and parenting backgrounds. Marital adjustment is a long process and must be performed continuously since it is not always easy. Wismanto (cited in Anjani \& Suryanto, 2006) supported this argument, stating that the process of understanding between partners will continue until one of them dies.

The process in marriage requires a willingness to accept the partners as they are, to be open towards each other and to have high tolerance, being able to share, to respect each other, and thus understanding their characteristics, values and culture (Anjani \& Suryanto, 2006). Since it can be concluded that humility and willingness to reduce the ego is very necessary, such adjustments in marriage can be made and conflicts can thus be avoided.

Conflicts in marriage generally relate to various factors, one of them being the household division of responsibilities (Scanzoi, cited in Sadarjoen, 2005). According to Arond and Pauker (cited in Olson \& DeFrain, 2003), this division is a major problem for men that often arises in marriage (Mintz \& Mahalik, 1996). Men who come from families who adhere to masculinity as a value will generally tend to face difficulties when dealing with domestic tasks and, according to Blazina (2001), this will cause low self-esteem. But the results of this study tend to be different, for the husband's self-esteem tends to be high. This finding becomes interesting because it is contrary to previous studies in marital adjustment.

Similar to other tribes, marriage in Karo also has a structure or rules applied in the society, though it is still possible to assimilate with other domination (Sembiring et al., 2002). Marriage in Karo culture comprises of some stages that has its own significance and value. The first stage is an introduction between both sides, not only to the couple, but also to their families. The second stage is nungkuni kata, in which the male family discusses (sukut anak beru) and decides the good day to visit the woman's. They are getting acquainted and proposing approval of the couple relationship (nungkun kata). Then, at the stage of ngembah belo selambar (bringing a sheet of betel leaf), they discuss the right time to have another family visit.

Before this third stage, another important ethical ritual is visiting Kalimbubu (uncle or mother's brother from the man, also called singalo ulu emas), with an intention that his niece (bere-berenya) gets married. Then, the man asks for the uncle's willingness to take part in ngembah belo selambar, in which stage both families discuss important subjects, such as negotiating the day to perform the next stage (nganting manuk or carrying a chicken), determining the dowry and the wedding party. After they agree upon the size of batang unjukan (dowry), they will negotiate the wedding party, which often takes quite a long time, being tough and tiring. The size of party symbolizes the prestige of each si nereh (related to the bride) family member. 
The last stage of the process is the wedding party, an embodiment of ngembah belo selambar. This stage consists of various types of traditional ceremonies, one of them being to pay the dowry (tukur) and give it to the parties who are entitled to receiving it. The term tukur means "buying" in Indonesian and it indicates an impression that the position of wife is lower because when a woman is "sold", she must follow her husband (Sebayang, 2013). This fact is in line with the patrilineal value held by Karo culture, where men are placed in a higher position than women.

Karo tribesmen have been prepared to be family leaders, to become the main breadwinners and to hold a higher social position than women. But after having a family, the reality is that these men are often faced with situations that conflict with the gender roles they have been socialized since childhood. Thus, men are required to be able to adjust to their new family conditions so that they can walk in harmony and avoid various problems, although the process is not easy.

Men perform some adjustment tasks in their marriage, even though sometimes it leads to low self-esteem because it contradicts with the demands of their gender roles as men (Helmreich \& Spence, 1978). In line with the results of Helmreich and Spence (1978), GBKP pastors' husbands have also made efforts at adjusting marriage. This can be seen from the results of a study (Brahmana \& Suyanto, 2018) conducted on the pastors' husbands, which found that domestic service and chores were carried out as a form of supporting the wife in the household, even though this was contrary to the Karo culture values that have been internalized since childhood. This study also showed that the GBKP pastor's husband was generally quite able to adjust to his marriage. Husbands willingness to support wives in housework and to carry out roles that are seen as contrary to their gender according to Latshaw (2015) have a positive impact on them, such as an increase in their selfesteem, because they feel that they are valuable and can make a significant contribution in the household. Thus, although the husband does not work as his wife does, he can contribute to the family in other ways.

\section{Self-Esteem Does Not Affect Gender Role Conflict of GBKP Pastor's Husband}

The results of the fifth hypothesis test showed that self-esteem does not significantly influence the husband's gender role conflict. This result becomes interesting because it tends to contradict previous studies, where selfesteem in general has a significant influence on male gender role conflict (Bem, 1974; Choi et al., 2010; O'Neil, 2008). Other studies conducted by Liu et al., 2005 (cited in Shek \& McEwen, 2012) also revealed that self-esteem has a significant negative relation to gender role conflict.

However, a study conducted by Liu and Iwamoto (2006) found contradictory results to previous researches, indicating that Asian culture value tends to correlate with increased gender role conflict on Asian men of American descent. Despite of experiencing a high gender role conflict, the self-esteem of Asian men of American descent remains high (Liu \& Iwamoto, 2006), which is similar to the findings in this study.

Some similarities were also found, particularly related to cultural values, between Asian men with American descent and GBKP pastors' husbands. Theoretically, Liu \& Iwamoto (2006) stated that some Asian culture values for men, such as their ability to control themselves and demands for success so that family dignity can be lifted, are generally similar to masculine values that are able to limit emotions and hopes for success. They have also argued that Asian-American men who support these cultural values generally experience gender role conflict in their life (Liu \& Iwamoto, 2006). 
Karo culture generally has similar values to the Asian culture. As the first adheres to the patrilineal culture, it also emphasizes that men can be successful and become breadwinners in order to maintain a good family name (Brahmana \& Suyanto, 2018; Meliala cited in Tophano, 2014). Since young age, men from Karo are demanded to be independent and "go to field", so that they can be breadwinners with influence (Bangun, 1981; Meliala cited in Tophano, 2014). In addition, Bangun (1981) argued that in Karo culture, men generally hold a higher position than women. Only men can make decisions and they are given a high position in traditional ceremonies (Bangun, 1981).

That the heavy demands and great responsibility can eventually lead to gender role conflict if men cannot fulfill their role demands is also supported by a study (Brahmana \& Suyanto, 2018) that found several causes to male gender role conflict, and in this case the pastors' husbands. These include socialization of gender roles, patriarchal cultural values, masculine ideologies and gender role transitions. Liu and Iwamoto (2006) found similar findings, in which Asian men with American descent who support Asian cultural values will generally also experience gender role conflict.

Liu and Iwamoto (2006) indicated that these Asian men who assumed to have already fulfilled gender role demands within themselves, and society, generally have a positive perspective on themselves. Liu and Iwamoto (2006) also stated that the high pride shown by those Asian men combines what the individual has performed (which is fulfilling individual's demand) and what a group of Asian culture demands and confirms (which is fulfilling a group's demand).

Based on the results of the seminar on Karo culture in 1977 (in Brahmana, 2003), it can be inferred that Karo society generally has special traits, such as being honest, brave, tough, well-mannered, tolerant, respecting others and also have a high self-esteem. Generally, Karo society maintains high self-esteem and they will do anything, even endure suffering, to keep their self-esteem high. The GBKP pastors' husbands presumably also possess this hereditary life principle and traits. Therefore, they still keep their pride even though they face difficulties, such as gender role conflicts.

\section{Conclusions}

Based on this research, it can be said that masculine ideology and marital adjustments affect gender role conflicts experienced by GBKP pastors' husbands, while self-esteem variables have no effect on gender role conflict on them. In addition, it is also shown that masculine ideology and marital adjustments do not affect their self-esteem.

\section{Limitation}

Although this study brings new findings related to the gender role conflict model in pastors' husbands, this work is not without limitation. The main limits in this study are related to the sample, which has very specific characteristics (GBKP pastors' husbands), so it cannot be generalized to pastors' husbands from other churches.

\section{Competing Interests}

The authors have declared no competing interests exist. 


\section{Funding}

The authors have no funding to report.

\section{Acknowledgments}

The study was supported by a research grant from Direktorat Jenderal Penguatan Riset dan Pengembangan Kementerian Riset, Teknologi, dan Pendidikan Tinggi Republic of Indonesia, based on the research contract number: 017/K1.1/ LT.1/2018.

\section{References}

Abdillah, W., \& Hartono, J. (2015). PLS (partial least square): Alternatif structural equation modelling dalam penelitian bisnis [PLS (partial least square): Alternative structural equation modeling in business research]. Yogyakarta, Indonesia: Andi.

Anjani, C., \& Suryanto. (2006). Pola penyesuaian perkawinan pada periode awal [Pattern of marital adjustment in the initial period]. INSAN, 8(3), 198-210.

Bangun, P. (1981). Pelapisan sosial di kabanjahe [Social coating in kabanjahe.] (Unpublished doctoral dissertation). Ilmu Antropologi Sosial University of Indonesia, Beji, Depok, Indonesia.

Bem, S. L. (1974). The measurement of psychological androgyny. Journal of Consulting and Clinical Psychology, 42(2), 155-162. https://doi.org/10.1037/h0036215

Blazina, C. (2001). Analytic psychology and gender role conflict: The development of the fragile masculine self. Psychotherapy, 38(1), 50-59. https://doi.org/10.1037/0033-3204.38.1.50

Brahmana, K. M. B., \& Suyanto, B. (2018). The dynamic of gender role conflict of pastors husbands at Batak Karo Protestant Church. Journal of Educational, Health and Community Psychology, 7(1), 38-60. https://doi.org/10.12928/jehcp.v7i2.8701

Brahmana, P. (2003). Daliken si telu dan solusi masalah sosial pada masyatakat karo: Kajian sistem pengendalian sosial [Three functional positions and solutions to social problems in the karo community: Study of social control systems]. Medan, Indonesia: Fakultas Sastra Jurusan Sastra Indonesia Universitas Sumatera Utara.

Choi, H., Kim, J. H., Hwang, M. H., \& Heppner, M. J. (2010). Self-esteem as a mediator between instrumentality, gender role conflict and depression in male Korean high school students. Sex Roles, 63(5-6), 361-372. https://doi.org/10.1007/s11199-010-9801-7

Courtenay, W. H. (2000). Constructions of masculinity and their influence on men's well-being: A theory of gender and health. Social Science \& Medicine, 50, 1385-1401. https://doi.org/10.1016/S0277-9536(99)00390-1

Ghozali, I. (2008). Aplikasi analisis multivariate dengan program SPSS [Multivariate analysis application with the SPSS program]. Semarang, Indonesia: Badan Penerbit Universitas Diponegoro.

Ghozali, I. (2014). Structural equation modeling, metode alternatif dengan partial least square (pls) edisi 4 [Structural equation modeling, alternative methods with partial least square (pls) 4th edition]. Semarang, Indonesia: Badan Penerbit Universitas Diponegoro. 
Good, G. E., Borst, T. S., \& Wallace, D. L. (1994). Masculinity research: A review and critique. Applied \& Preventive Psychology, 3, 3-14. https://doi.org/10.1016/S0962-1849(05)80104-0

Good, G. E., Walther, D. J., \& Heppner, P. P. (1995). The differential role of instrumentality, expressivity, and social support in predicting problem-solving appraisal in men and women. Sex Roles, 32, 134-153.

Hair, J. F. J., Anderson, R. E., Tatham, R. L., \& Black, W. C. (1998). Multivariate data analysis (5th ed.). London, United Kingdom, Pearson Education.

Hair, J. F. J., Jr., Anderson, R. E., Tatham, R. L., \& Black, W. C. (2006), Multivariate data analysis (6th ed.). London, United Kingdom: Pearson Education.

Hartono, J., \& Abdillah, W. (2014). Partial least square. Yogyakarta, Indonesia: Andi.

Helmreich, R. L., \& Spence, J. T. (1978). Masculinity \& femininity. Their psychological dimensions, correlates, and antecedents. Austin, TX, USA: University of Texas Press.

Hurlock, E. B. (1991). Psikologi perkembangan: Suatu pendekatan sepanjang rentang kehidupan [Developmental psychology: An approach throughout life span] ( $5^{\text {th }}$ ed.). Jakarta, Indonesia: Erlangga.

Latshaw, B. A. (2015). From mopping to mowing: Masculinity and housework in stay-at-home father households. The Journal of Men's Studies, 23(3), 252-270. https://doi.org/10.1177/1060826515600880

Laswell, M., \& Laswell, T. (1987). Marriage and the family. Belmont, CA, USA: Wadsworth Publishing.

Liu, W. M., \& Iwamoto, D. K. (2006). Asian American men's gender role conflict: The role of Asian values, self-esteem, and psychological distress. Psychology of Men \& Masculinity, 7(3), 153-164. https://doi.org/10.1037/1524-9220.7.3.153

Liu, W. M., Rochlen, A., \& Mohr, J. J. (2005). Real and ideal gender-role conflict: Exploring psychological distress among men. Psychology of Men \& Masculinity, 6(2), 137-148. https://doi.org/10.1037/1524-9220.6.2.137

Mellinger, C., \& Levant, R. F. (2014). Moderators of the relationship between masculinity and sexual prejudice in men: Friendship, gender self-esteem, same-sex attraction, and religious fundamentalism. Archives of Sexual Behavior, 43, 519-530. https://doi.org/10.1007/s10508-013-0220-z

Mintz, R. D., \& Mahalik, J. R. (1996). Gender role orientation and conflict as predictors of family roles for men. Sex Roles, 34(11-12), 805-821. https://doi.org/10.1007/BF01544317

Olson, D. H., \& DeFrain, J. (2003). Marriages and families: Intimacy, diversity and strength (4th ed.). New York, NY, USA: McGraw Hill.

O'Neil, J. M. (1981). Patterns of gender role conflict and strain: Sexism and fear of femininity in men's lives. The Personnel and Guidance Journal, 60, 203-210. https://doi.org/10.1002/j.2164-4918.1981.tb00282.x

O'Neil, J. M. (2008). Summarizing 25 years of research on men's gender role conflict using the gender role conflict scale: New research paradigms and clinical implications. The Counseling Psychologist, 36, 358-445. https://doi.org/10.1177/0011000008317057

O'Neil, J. M. (2015). Men's gender role conflict: Psychological cost, consequences, and an agenda for change. Washington, DC, USA: American Psychological Association. 
O’Neil, J. M., \& Egan, J. (1992). Men's gender role transitions over the life span: Transformations and fears of femininity. Journal of Mental Health Counseling, 14, 305-324.

O'Neil, J. M., \& Fishman, D. (1992). Adult men's career transitions and gender role themes. In H. D. Lee \& Z. B. Leibowitz (Eds.), Adult career development: Concepts, issues, and practices (pp. 132-162). Alexandria, VA, USA: ACA Press.

O'Neil, J. M., Fishman, D. M., \& Kinsella-Shaw, M. (1987). Dual-career couples' career transitions and normative dilemmas: A preliminary assessment model. The Counseling Psychologist, 15, 50-96. https://doi.org/10.1177/0011000087151003

O'Neil, J. M., Helms, B., Gable, R., David, L., \& Wrightsman, L. (1986). Gender role conflict scale (GRCS): College men's fears of femininity. Sex Roles, 14, 335-350. https://doi.org/10.1007/BF00287583

Pleck, J. H. (1995). The gender role strain paradigm: An update. In R. F. Levant \& W. S. Pollack (Eds.), A new psychology of men (pp. 11-32). New York, NY, USA: Basic Books.

Pleck, J. H., Sonenstein, F. L., \& Ku, L. C. (1993). Masculinity ideology and its correlates. In S. Oskamp \& M. Costanzo (Eds.), Gender issues in social psychology (pp. 85-110). Newbury Park, CA, USA: Sage.

PPWG GBKP. (2014). Bahan kursus calon pertua diaken GBKP periode 2014-2019 [Course material for pertua diaken of the GBKP for the 2014-2019 periods]. Kabanjahe, Indonesia: Percetakan GBKP Abdi Karya Kabanjahe.

Raykov, T. (2001). Bias of coefficient alpha for congeneric measures with correlated errors. Applied Psychological Measurement, 25, 69-76. https://doi.org/10.1177/01466216010251005

Rosenberg, M. (1979). Conceiving the self. New York, NY, USA: Basic Books.

Sadarjoen, S. S. (2005). Konflik marital: Pemahaman konseptual, actual dan alternative solusinya [Marital conflict: Understanding of conceptual, actual and alternative solutions]. Bandung, Indonesia: Refika Aditama.

Sebayang, M. B. (2013). Relasi istri dan suami dalam masyarakat karo (tinjauan teologi feminis terhadap relasi istri dan suami dalam masyarakat suku karo) [Relationship of wife and husband in the karo community (a review of feminist theology of the relationship of the wife and husband in the Karo tribe society)]. (Unpublished undergraduate thesis). Universitas Kristen Duta Wacana, Semarang, Indonesia.

Sembiring, S. H., Sibero, B. T., Manik, S. D. G., Munte, M. G., \& Sibero, G. T. (2002). Adat perkawinan masyarakat batak karo [Traditional marriage of the Karo Batak people]. [Seminar]. Yogyakarta, Indonesia: Perpulungen Arih Ersada.

Shek, Y. L., \& McEwen, M. K. (2012). The relationships of racial identity and gender role conflict to self-esteem of Asian American undergraduate men. Journal of College Student Development, 53(5), 703-718. https://doi.org/10.1353/csd.2012.0065

Spanier, G. B. (1976). Measuring dyadic adjustment: New scales for assessing the quality of marriage and similar dyads. Journal of Marriage and the Family, 38(1), 15-28. https://doi.org/10.2307/350547

Tarigan, S. (2009). Lentera kehidupan orang karo dalam berbudaya [The lanterns of karo people in culture]. Medan, Indonesia: BNB Press.

Thompson, E. H., \& Pleck, J. H. (1986). The structure of the male norms. The American Behavioral Scientist, $29,531-543$. https://doi.org/10.1177/000276486029005003 
Tophano, E. K. (2014). Gambaran preferensi pemilihan pasangan pada mahasiswa suku karo di universitas sumatera utara [Picture of preference for partner selection in Karo tribe students at the University of North Sumatra]. (Unpublished undergraduate Thesis). Fakultas Psikologi Universitas Sumatera Utara, Medan, Indonesia.

Wade, J. C., \& Rochlen, A. B. (2013). Introduction: Masculinity, identity, and the health and well-being of African American men. Psychology of Men \& Masculinity, 14(1), 1-6. https://doi.org/10.1037/a0029612

Wood, W., \& Eagly, A. (2002). A cross-cultural analysis of the behavior of women and men: Implications for the origins of sex differences. Psychological Bulletin, 128, 699-727. https://doi.org/10.1037/0033-2909.128.5.699 